Prepared in cooperation with the City of Wichita, Kansas, as part of the Equus Beds Groundwater Recharge Project

\title{
Water Quality of the Little Arkansas River and Equus Beds Aquifer Before and Concurrent with Large-Scale Artificial Recharge, South-Central Kansas, 1995-2012
}

\author{
By Daniel J. Tappa, Jennifer L. Lanning-Rush, and Andrew C. Ziegler
}

\section{Abstract}

This fact sheet describes baseline water quality of the Equus Beds aquifer and Little Arkansas River and water-quality effects of artificial recharge by the city of Wichita associated with Phase I (2007-present) of the Aquifer Storage and Recovery project. During 1995 through 2012, more than 8,800 surface water and groundwater water-quality samples were collected and analyzed for more than 400 compounds, including most of the compounds on the U.S. Environmental Protection Agency's primary drinking-water standards maximum contaminant level list and secondary drinkingwater regulations secondary maximum contaminant level list. Water-quality constituents of concern discussed in detail in this fact sheet are chloride, arsenic, total coliform bacteria, and atrazine. Sulfate, nitrate, iron, manganese, oxidation-reduction potential, and specific conductance also are constituents of concern and are discussed to a lesser extent.

\section{Introduction}

The city of Wichita relies on groundwater from the Equus Beds aquifer and surface water from Cheney Reservoir for their municipal water supply (fig. 1). After several drought years in the late 1980s and early 1990s, 1993 aquifer water levels were as much as 50 feet lower than predevelopment (1940) levels. Exacerbating concerns regarding aquifer drawdown was the movement of a large chloride plume near Burrton, Kansas, from previous oil and gas exploration and naturally high chloride concentrations from the Arkansas River moving towards the city's municipal well field (Ziegler and others, 1999; fig. 1). This prompted the city of Wichita to investigate and implement artificial recharge of the Equus Beds aquifer, beginning in 1997, by using water from the Little Arkansas River when streamflow exceeds base-flow requirements.

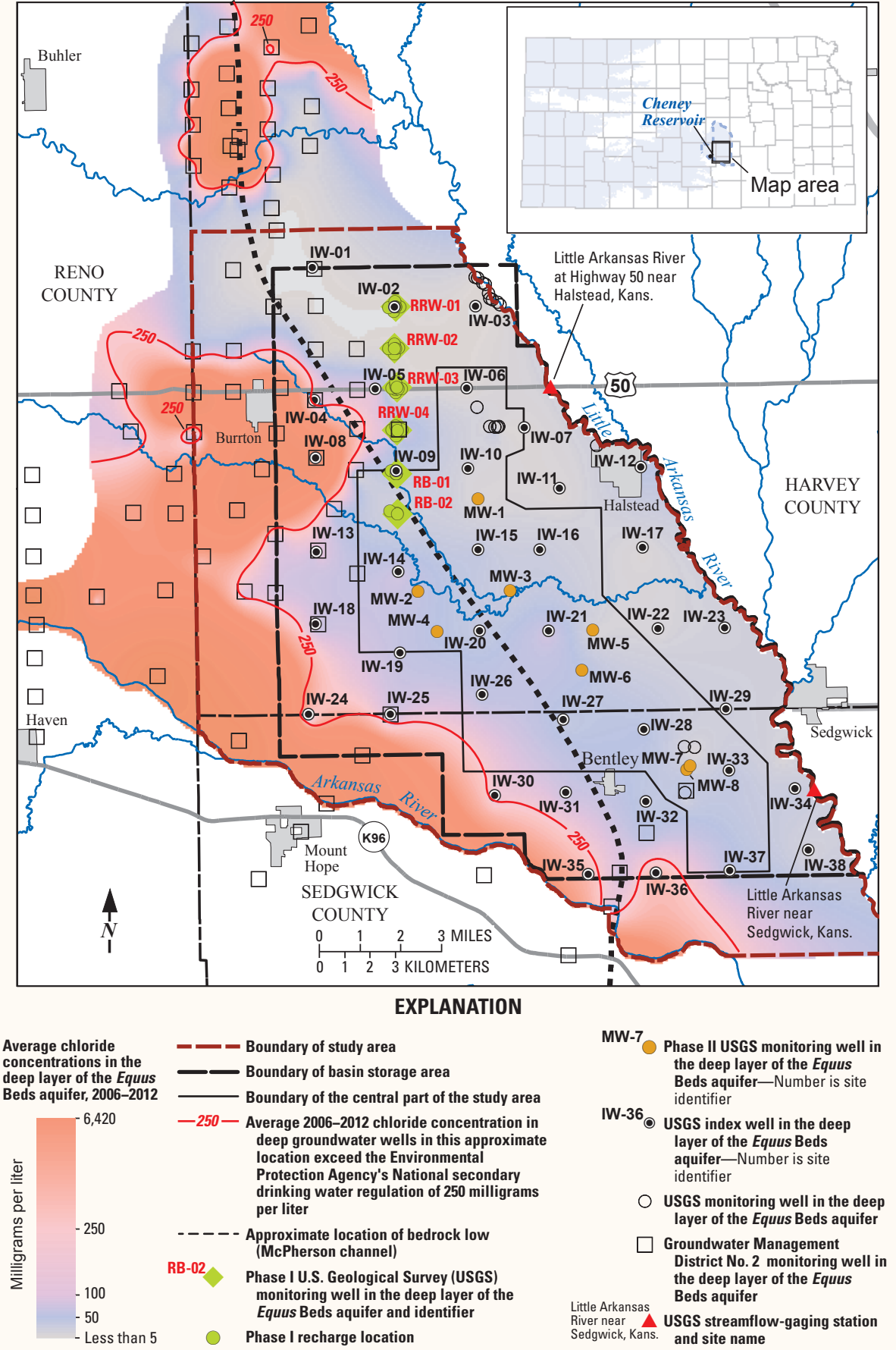

Figure 1. Average chloride concentrations in and near the study area for deep wells, 2006-2012, south-central Kansas. 
The purpose of this fact sheet is to describe Equus Beds aquifer and Little Arkansas River water quality during 1995 through 2012, including quantifying effects related to Phase I recharge activities of about 1 billion gallons during 2007 through 2012. This fact sheet is part of a long-term cooperative investigation (since 1940) between the city of Wichita and the United States Geological Survey to describe water quantity and quality conditions in the Equus Beds aquifer and the Little Arkansas River; and, more recently (since 1995), potential effects of artificial recharge on water resources in south-central Kansas. This description of water-quality conditions serves as a baseline to detect any subsequent water-quality changes of the Equus Beds aquifer and the Little Arkansas River during Phase II, which increased recharge design capacity by 30 million gallons per day in 2013. Refer to Tappa and others (2015) for more details about material presented in this fact sheet.

\section{Artificial Recharge and Water Quality}

\section{Chloride}

Chloride is a major constituent of concern because of its persistence in groundwater from a chloride plume near Burrton, Kans., and because of highly variable concentrations in the Little Arkansas River that can exceed drinking-water standards (Ziegler and others, 1999). The Federal secondary maximum contaminant level (SMCL) for chloride is 250 milligrams per liter (milligrams per liter [mg/L]; U.S. Environmental Protection Agency, 2009) for aesthetics, including taste and odor, and was exceeded in about 11 percent of samples from two surfacewater monitoring sites on the Little Arkansas River during 1995 through 2012 (table 1). Chloride concentrations ranged from less than 5 to $932 \mathrm{mg} / \mathrm{L}$.

During 2001 through 2012, chloride concentrations exceeded the SMCL in 5.6 percent of samples from shallow areal assessment index wells (IWs) and 7.4 percent of samples from deep IWs. Concentrations exceeding $250 \mathrm{mg} / \mathrm{L}$ in deep

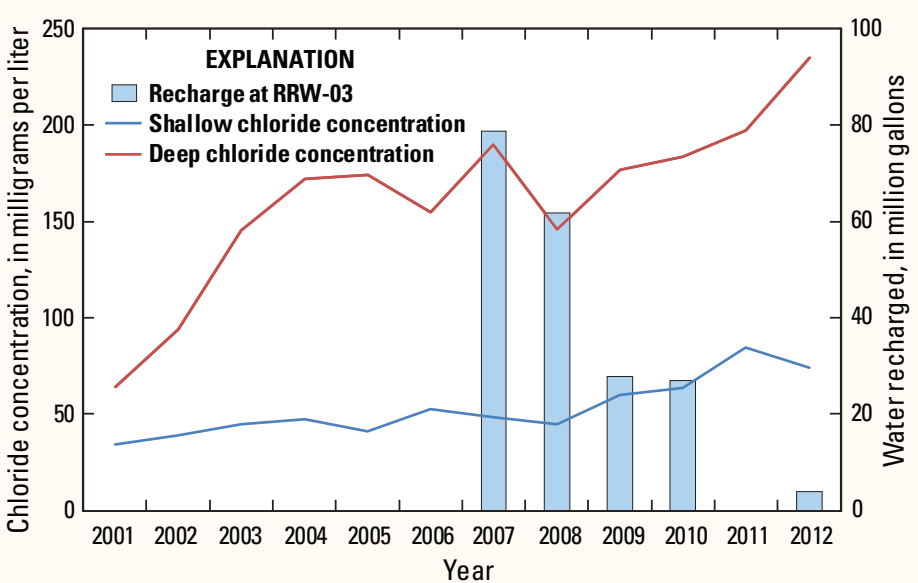

Figure 2. Chloride concentrations in IW-05 (shallow and deep) and Phase I recharge at RRW-03 in the Equus Beds aquifer near Burrton, Kansas, 2001-2012. parts of the aquifer were detected in wells located near Burrton, Kans., and along the Arkansas River during 2006-2012 (fig. 1). Average chloride concentrations of all IWs (shallow and deep) decreased during 2007-2012 compared to 2001-2006 averages; however, median chloride concentrations increased from the first period to the second (table 2). The Burrton chloride plume was impeded or diluted at IW-05, which is about 0.5 miles west of a Phase I recharge well (RRW-03; fig. 1). Chloride concentrations stabilized with Phase I recharge at RRW-03 in 2007 through 2010, and concentrations began to increase after 2010 when Phase I recharge was minimal (fig. 2). Chloride movement through the Equus Beds aquifer is complex as a result of discontinuous clay and sand layers. The clay layers act as barriers, slowing the vertical movement of groundwater in certain areas, whereas sand layers allow groundwater to flow more easily.

\section{Arsenic}

Arsenic occurs naturally in clay layers associated with iron sulfide minerals (Hem, 1992), and can be a health hazard to humans (U.S. Environmental Protection Agency, 2005). The Federal maximum contaminant level (MCL) for arsenic is 10 micrograms per liter $(\mu \mathrm{g} / \mathrm{L}$; U.S. Environmental Protection Agency, 2009). Water samples collected from the Little Arkansas River near Halstead, Kans., and near Sedgwick, Kans., from 1995 through 2012 had a median and average dissolved arsenic concentration of about $5 \mu \mathrm{g} / \mathrm{L}$, which is one-half the MCL for arsenic. Dissolved arsenic concentrations ranged from less than 1 to $15.9 \mu \mathrm{g} / \mathrm{L}$ and exceeded the MCL in about 11 percent of the samples from the Little Arkansas River (table 1). During 1995-2012, dissolved arsenic concentrations exceeded $10 \mu \mathrm{g} / \mathrm{L}$ in water samples from 12 percent of shallow IWs and nearly 35 percent of samples from deep IWs. Larger concentrations of arsenic in the deep parts of the aquifer occurred on the west side of the study area and on the eastern side of the study area along the Little Arkansas River (fig. 3). Sources of arsenic in the Equus Beds aquifer are natural; however, changes in groundwater chemistry can result in changes in arsenic concentrations.

\section{Total Coliform Bacteria}

Coliform bacteria are a bacterial indicator that indicate presence of pathogenic organisms. The U.S. Environmental Protection Agency (EPA) Federal Maximum Contaminant Level Goal (MCLG) in drinking water for total coliform bacteria is that no more than 5 percent of samples test positive during 1 month for water systems that collect at least 40 routine samples per month (U.S. Environmental Protection Agency, 2009). In 2009, bacterial and viral indicators were detected at elevated levels in monitoring wells near RB-1 (fig. 1; Garinger and others, 2011).

Approximately 95 percent of the samples collected from the two sites on the Little Arkansas River had total coliform bacteria detections (table 1), which indicates that the MCLG for total coliforms was rarely met at these sites. Coliform bacteria 


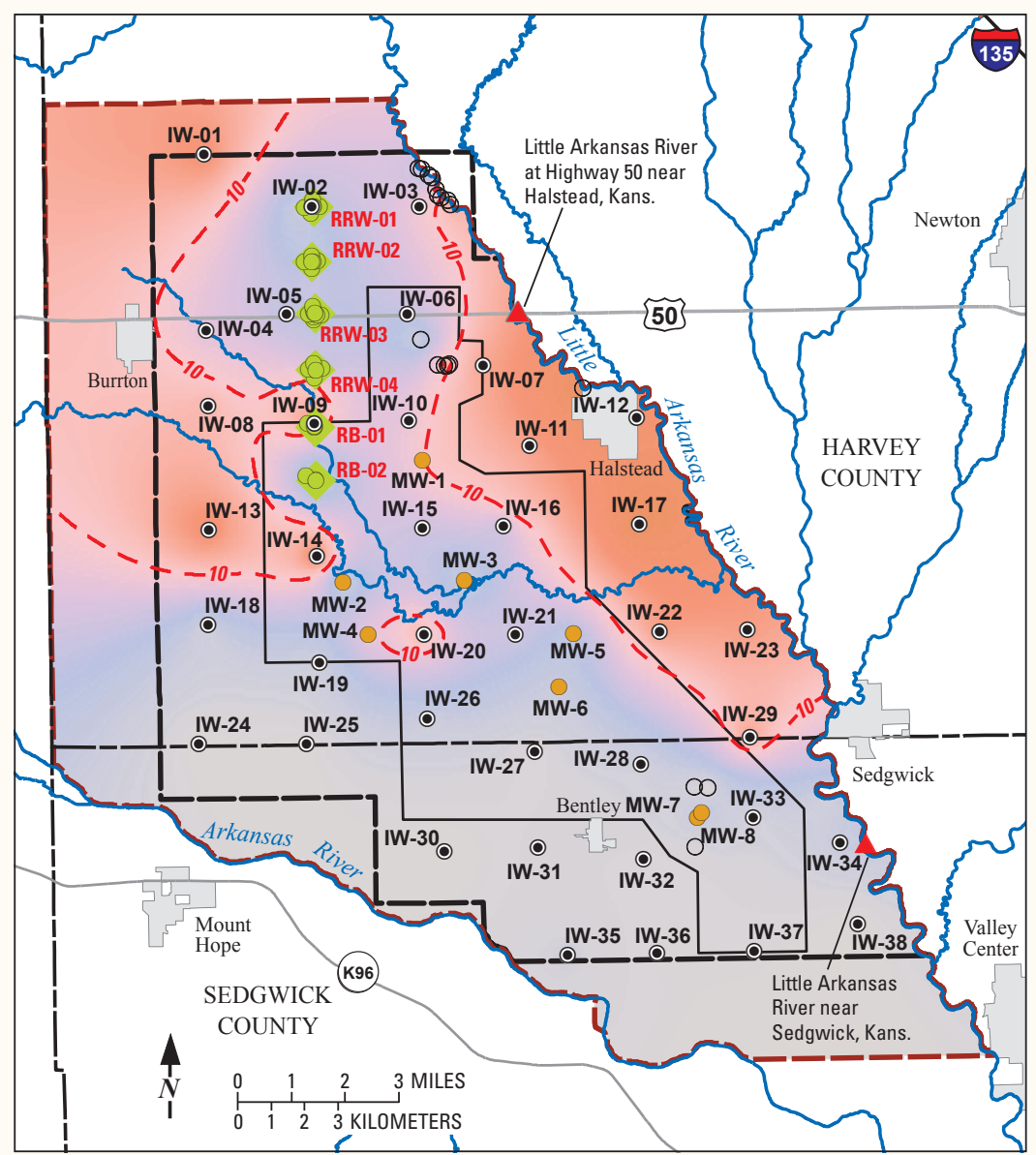

EXPLANATION
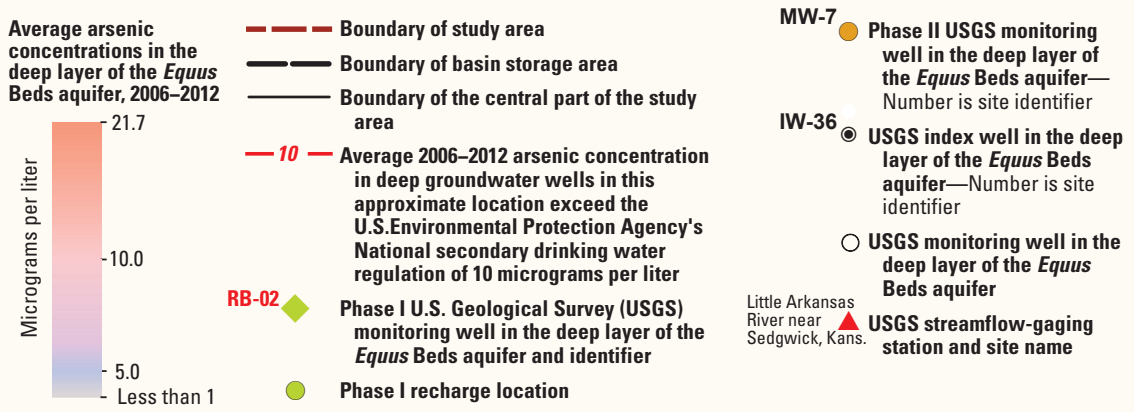

Figure 3. Average arsenic concentrations in the study area, 2006-2012, in deep wells.

detections in water samples collected from the Little Arkansas River during this period were as large as 2,000,000 colonies per 100 milliliters (col/100 mL) near Halstead, Kans., and as large as 9,000,000 col/100 mL near Sedgwick, Kans. Total coliform densities in groundwater were substantially lower than in samples from the Little Arkansas River. Total coliform detections exceeded the EPA Federal MCLG of 0 colonies in water samples from 25 percent of the shallow IWs and in 12 percent of the deep IWs in the aquifer. Many of these detections were in the first samples collected from wells after they were developed, indicating that at least some of these detections were likely related to the drilling process.

\section{Atrazine}

Atrazine is an herbicide used on corn and grain sorghum, crops commonly grown in and near the study area, and it does not occur naturally in the environment (Ziegler and others, 2010). The Federal MCL for atrazine in drinking water is $3.0 \mu \mathrm{g} / \mathrm{L}$ as an annual average (U.S. Environmental Protection Agency, 2009). During 1995-2012, the average atrazine concentration was $3.6 \mu \mathrm{g} / \mathrm{L}$ from all samples collected from the two Little Arkansas River surface water sites (table 1). Atrazine concentrations larger than the MCL of $3.0 \mu \mathrm{g} / \mathrm{L}$ generally occur in the Little Arkansas River from late spring to early fall. Average atrazine concentrations were less than $0.1 \mu \mathrm{g} / \mathrm{L}$ in both shallow and deep IWs during 1995-2012.

\section{Equus Beds Water-Quality Changes}

Constituents and physical properties of interest for shallow and deep IWs include arsenic, chloride, iron, manganese, nitrite plus nitrate, oxidation-reduction potential (ORP), specific conductance, and sulfate. As a group, all constituents of interest except chloride, arsenic, and ORP had the average value increase from the 2001 to 2006 period to the 2007 to 2012 period in the IW network (table 2). Average concentration increases for constituents of interest and the ORP decrease from 2006 to 2012 is likely linked to drought conditions during 2011-2012 (Hansen and others, 2014). Lower precipitation amounts limit the diluting effect of new-water recharge.

Artificial recharge activities associated with Phase I have not resulted in substantial effects on groundwater quality in the area. The amount of water recharged associated with Phase I is relatively small (1 billion gallons) compared to the aquifer storage in the winter of 2012 of approximately 990 billion gallons (Hansen and others, 2014). An exception is the temporary stabilization of chloride concentrations in the north-central part of the study area near the Burrton chloride plume. Water-quality constituents of concern outlined here have not increased substantially and are likely more affected by climatological (natural recharge by precipitation) and natural (geochemical oxidation/reduction, metabolic and decay rates) processes than artificial recharge. Arsenic remains a water-quality constituent of concern because of natural and continued persistence of concentrations exceeding the Federal MCL, especially in the deeper parts of the Equus Beds aquifer. 
Table 1. Little Arkansas River and Equus Beds Aquifer water quality summary.

$[n$, number of samples; mg/L, milligrams per liter; $\mu \mathrm{g} / \mathrm{L}$, micrograms per liter; col/100 mL, colonies per 100 milliliters; <, less than; EPA, U.S. Environmental Protection Agency]

\begin{tabular}{|c|c|c|c|c|c|}
\hline Constituent & Water-quality criteria & $n$ & Average & Median & $\begin{array}{l}\text { Percent } \\
\text { exceeding }\end{array}$ \\
\hline \multicolumn{6}{|c|}{ Little Arkansas River (1995-2012) } \\
\hline Chloride & $250 \mathrm{mg} / \mathrm{L}^{\mathrm{a}}$ & 501 & 110 & 97 & 11 \\
\hline Arsenic & $10 \mu \mathrm{g} / \mathrm{L}^{\mathrm{b}}$ & 314 & 5.6 & 4.8 & 11 \\
\hline Total coliform bacteria & 0 cols $/ 100 \mathrm{~mL}^{\mathrm{c}}$ & 380 & 39,000 & 1,500 & 95 \\
\hline Atrazine & $3 \mu \mathrm{g} / \mathrm{L}$ as annual average ${ }^{\mathrm{b}}$ & 4,888 & 3.6 & 1.7 & 33 \\
\hline \multicolumn{6}{|c|}{ Shallow index wells (2001-2012) } \\
\hline Chloride & $250 \mathrm{mg} / \mathrm{L}^{\mathrm{a}}$ & 568 & 70 & 36 & 5.6 \\
\hline Arsenic & $10 \mu \mathrm{g} / \mathrm{L}^{\mathrm{b}}$ & 563 & 3.9 & 1.6 & 12 \\
\hline Total coliform bacteria & 0 cols $/ 100 \mathrm{~mL}^{\mathrm{c}}$ & 441 & 6.4 & 0.1 & 25 \\
\hline Atrazine & $3 \mu \mathrm{g} / \mathrm{L}$ as annual average ${ }^{b}$ & 761 & $<0.1$ & $<0.1$ & 0 \\
\hline \multicolumn{6}{|c|}{ Deep index wells (2001-2012) } \\
\hline Chloride & $250 \mathrm{mg} / \mathrm{L}^{\mathrm{a}}$ & 568 & 116 & 65 & 7.4 \\
\hline Arsenic & $10 \mu \mathrm{g} / \mathrm{L}^{\mathrm{b}}$ & 563 & 7.4 & 5.9 & 35 \\
\hline Total coliform bacteria & 0 cols $/ 100 \mathrm{~mL}^{\mathrm{c}}$ & 443 & 1.2 & $<0.1$ & 12 \\
\hline Atrazine & $3 \mu \mathrm{g} / \mathrm{L}$ as annual average ${ }^{\mathrm{b}}$ & 686 & $<0.1$ & $<0.1$ & 0 \\
\hline \multicolumn{6}{|c|}{${ }^{\mathrm{a} E P A}$ Secondary Drinking Water Regulation. } \\
\hline \multicolumn{6}{|c|}{ 'EPA Maximum Contaminant Level. } \\
\hline \multicolumn{6}{|c|}{ 'EPA Maximum Contaminant Level Goal. } \\
\hline
\end{tabular}

\section{References Cited}

Garinger, L.P., King, A., and Ziegler, A.C., 2011, Effects of experimental passive artificial recharge of treated surface water on water quality in the Equus Beds aquifer, 20092010: U.S. Geological Survey Scientific Investigations Report 2011-5070, 106 p.

Hansen, C.V., Whisnant, J.A., and Lanning-Rush, J.L., 2014, Status of groundwater levels and storage volume in the Equus Beds aquifer near Wichita, Kansas, 2012 to 2014: U.S. Geological Survey Scientific Investigations Report 2014-5185, 39 p.

Hem, J.D., 1992, Study and interpretation of chemical characteristics of natural water (3d ed.): U.S. Geological Survey Water-Supply Paper 2254, $263 \mathrm{p}$.

U.S. Environmental Protection Agency, 2005, Current drinkingwater standards: accessed August 17, 2005, at http://water. epa.gov/drink/contaminants/index.cfm.

U.S. Environmental Protection Agency, 2006, 2006 Edition of the drinking water standards and health advisories: Office of Water, EPA 822-R-06-013, August 2006, 12 p., accessed December 13, 2007, at http://water.epa.gov/drink/standards/ hascience.cfm.

Ziegler, A.C., Christensen, V.G., and Ross, H.C., 1999, Baseline water-quality and preliminary effects of artificial recharge on groundwater, south-central Kansas, 1995-98: U.S. Geological Survey Water-Resources Investigations Report 99-4250, $74 \mathrm{p}$.

Ziegler, A.C., Hansen, C.V., and Finn, D.A., 2010, Water quality in the Equus Beds aquifer and the Little Arkansas River before implementation of large-scale artificial recharge, south-central Kansas, 1995-2005: U.S. Geological Survey Scientific Investigations Report 2010-5023, 143 p.

For additional information concerning this publication, contact: Director, USGS Kansas Water Science Center 4821 Quail Crest Place

Lawrence, KS 66049

(785) 842-9909

\section{Or visit the Kansas Water Science Center Web site at:} http://ks.water.usgs.gov

$2007-2012 \quad 862 \quad 953$

